\section{Legacy of the Nazis}

SIR-The recent discovery in German institutions of anatomical specimens derived from victims of the Nazis has profound implications for medicine and medical science. Nature is the only scientific journal so far to report these findings. The relative silence of the scientific press appears to support the concern expressed by the director of one of the institutions involved, the Max Planck Institute of Brain Research, "that the reputation of science might suffer from further publicity".

While Western medicine is seeking to come to grips, in a meaningful way, with medical ethics, it overlooks an issue that challenges the ethical basis of medicine. Ironically, modern medical ethics arose from the experience of Nazi medicine, in particular medical experimentation conducted on unwitting subjects imprisoned in concentration or death camps. The Nuremburg code on medical experimentation was formulated at the War Crimes Tribunal; have medical ethicists forgotten the origins of their discipline?

Now, ironically, while responsible German institutions acknowledge the possession of these specimens and are considering plans for their proper disposal, the medical and scientific community elsewhere remains largely ignorant and silent on the issue. In the long term, that will damage the reputation of science and medicine. Although the medical profession has now effectively dissociated itself from Nazi medicine, which is regarded as an isolated example of evil practised by a few SS physicians, in reality Nazi medicine involved virtually the entire German health-care system in racial selection, enforced sterilization, 'euthanasia' of the mentally ill, research into racial hygiene and genetics and various forms of forbidden medical experimentation. Courses on racial hygiene became part of the undergraduate medical curriculum ${ }^{2.3}$. Yet medicine today continues to ignore the links between medicine in Hitler's Germany and medicine elsewhere.

Scientific medicine developed, for the most part, in the Germany of Koch, Virchow, Roentgen and Erlich. The institutions that acquired and used these specimens are part of the system of medical education that was a model for the modern North American system. Abraham Flexner, the architect of the North American system of medical education, saw the German university system as a model for merging the university and science in the training of physicians ${ }^{4}$. The Nazi physicians responsible for some of the worst evils in recorded history were graduates of this same university system.

That is why this tragic episode of these anatomical specimens must become more widely known. The specimens should not only receive a respectful burial but their existence and burial should be acknowledged and commemorated by all of medicine. There must be public documentation of who those people once were, how they died and how institutions representing science, medicine and higher education used their remains for almost half a century after the defeat of the Nazi regime. A proper documentation and public burial would help to sensitize the profession, and the world, to the fallibility of medicine and the vulnerability of human society.

\section{North Hamilton Community}

\section{Health Centre,}

554 John Street North,

Hamilton, Ontario L8L 4SI, Canada

1. Dickman, S. Nature 337, 195; 339, 498 (1989).

2. Müller-Hill, B. Murderous Science (Oxford University Press, 1988).

3. Proctor, R. Racial Hygiene: Medicine Under the Nazis (Harvard University Press, 1988).

4. Flexner, A. I Remember (Simon and Schuster, New York, 1940)

\section{Stanford maligned}

SIR-I have just read Alex Comfort's review of Stalking the academic Communist: Intellectual freedom and the firing of Alex Novikoff by David Holmes (Nature 339, 347 ; 1989)

In it, the following sentence appears, in connection with Comfort's claim that academics generally show cowardice in the face of external attack: "If anyone thinks that this was a feature of a unique period, they should have been at Stanford a few years ago when an equally malicious but non-political attack on a distinguished scientific faculty member - also Jewish found his colleagues, including his Jewish colleagues, looking at their blotting pads in equal silence."

I have been at Stanford for 30 years as a member of the science faculty, and for the past nine as its president. I have no idea what Comfort is talking about. For all I know, there may be a case to be made somewhere. But Comfort doesn't make it; he merely inserts a piece of offhand institutional slander so lacking in documentation that one cannot even identify its source.

\section{Stanford University,}

Stanford, California 94305-2060, USA

\section{Guidelines needed}

SIR-Authors of research papers are apparently not the only ones in the scientific enterprise in need of publication guidelines and oversight mechanisms. A journal editor recently held a manuscript of mine for four months before it became clear that he had never sent it out for review and did not wish to do so until I could be persuaded to cite his research. When I refused (because his papers were only marginally relevant), he reluctantly proposed to send the manuscript to two reviewers, with, he said, "my anonymous comments regarding its merits and faults".

The behaviour of this editor is, I believe, contrary to custom and certainly to what the scientific community expects. Such lapses could, to some extent, be prevented or redressed. On the page or pages where a journal now gives its instructions to authors (often demanding a lot in the way of form and format), it should also set out its own guidelines on editorial policy, and say who is responsible for them. It could be stated, for example, that the society's board of directors, or the publishers, had agreed on the listed guidelines. These would include how a manuscript is processed, how many reviewers are used, how long a decision is expected to take, and so on. It is important that a publisher or board should participate in setting guidelines and, when necessary, take part in implementing them. Abuses go unreported in systems where the culprit has been appointed judge, jury and court of appeal.

RICHARD F. SHAW 10201 Grosvenor Place, Apt 522, Bethesda, Maryland 20852, USA

\section{German or Polish?}

SIR-Steven Dickman writes (Nature 340, $497 ; 1989)$ that the 'Hall of Fame' of the German Museum in Munich "contains busts of 38 'German' scientific greats, from Copernicus (a Pole) to Einstein", thus implying that not all the 'greats' were German, and certainly not Copernicus. One could well argue about the purpose of halls of fame, and Copernicus himself would probably turn in his grave at the thought of Poles and Germans staking claims to his presumed loyalties, but, to be fair to the museum, he was born into an ethnic German family and raised in a German-speaking community. His native town, Thorn (today's Toruń), was first occupied by Poland less than seven years before his birth, and although now an integral part of the Polish nation, its German population was replaced by ethnic Poles only gradually during the past 100 years. By the criteria of his time, Copernicus was a German, as his association with the German 'nation' among his fellow students at Padua University illustrates; by the current definition of nationality, maybe he was a Pole as well. Copernicus, perhaps, is big enough for two halls of fame.

HERMAN REICHENBACH 2000 Hamburg 61, FRG 